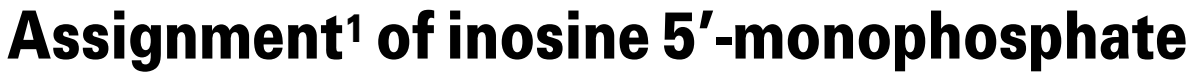 dehydrogenase type 2 (IMPDH2) to human chromosome band 3p21.2 by in situ hybridization
}

\author{
M.V. Kost-Alimova, ${ }^{a}$ D.A. Glesne, ${ }^{b}$ E. Huberman ${ }^{b}$ and A.V. Zelenin ${ }^{a}$ \\ a Engelhardt Institute of Molecular Biology, Russian Academy of Sciences, Moscow (Russia); \\ ${ }^{\mathrm{b}}$ Center for Mechanistic Biology and Biotechnology, Argonne National Laboratory, Argonne, IL (USA) \\ ${ }^{1}$ This is a more precise localization of a gene previously mapped to $3 \mathrm{p} 24.2 \rightarrow \mathrm{p} 21.2$ by Glesne et al. (1993).
}

\section{Rationale and significance}

Inosine 5'-monophosphate dehydrogenase (IMPDH, E.C. 1.1.1.205) is the rate limiting enzyme in de novo guanine nucleotide biosynthesis, and is encoded by two genes termed types I and II. Increased IMPDH activity has been found in an assortment of tumors (Collart et al., 1992), while decreased IMPDH activity has been observed during differentiation of various cell types (Kiguchi et al., 1990, and references therein). This regulation is reportedly due to changes in the level of the type II mRNA, whereas the type I mRNA is constitutively expressed (Natsumeda and Carr, 1993). We here report the localization of the type II IMPDH gene (IMPDH2) to a region that is either deleted or has undergone loss of heterozygosity in a wide variety of human tumors (reviewed in Naylor et al., 1996).

Fig. 1. Fluorescent in situ hybridization with a probe specific to human IMPDH2, detected either with FITC (a, b) or Texas Red-conjugated avidin (c) on metaphase chromosomes stained with DAPI $(\mathbf{a}, \mathbf{b})$ or FITC and R replicative banding (c).
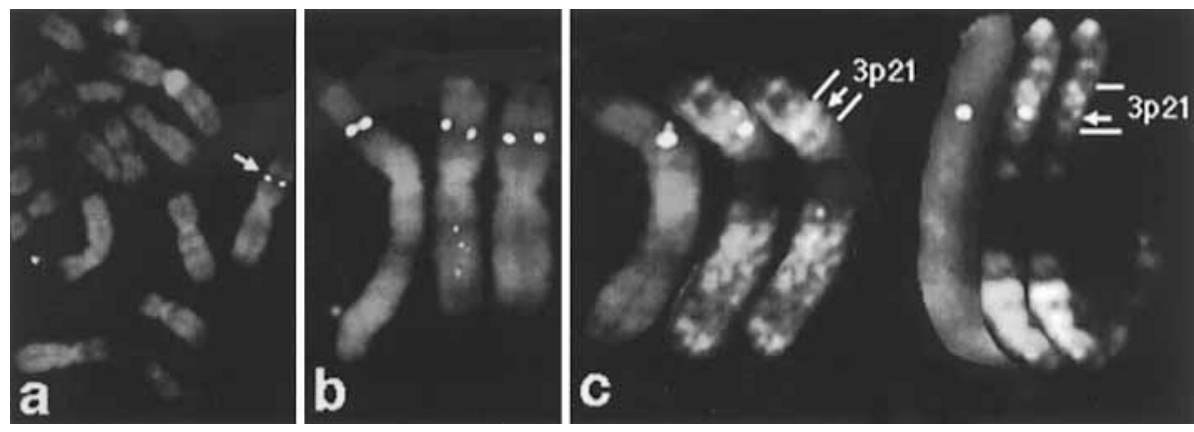

Supported by the Russian National Human Genome Project and Russian Support for Scientific Schools (96-15-97640), and the U.S. Department of Energy, Office of Biological and Environmental Research, under contract W-31-109-ENG-38.

Received 19 May 1998; manuscript accepted 25 May 1998.

Request reprints from E. Huberman, Ph.D., Center for Mechanistic Biology and Biotechnology, Argonne National Laboratory, Argonne, IL 60439 (USA); telephone: (630) 252-3819; fax: (630) 252-3853; e-mail: elih@anl.gov \begin{tabular}{ll}
\hline KARGER & $\begin{array}{l}\text { E-mail karger@karger.ch } \\
\text { Fax }+41613061234\end{array}$ \\
\end{tabular} http://www.karger.com

\section{Materials and methods}

Human phytohemagglutinin-stimulated lymphocytes were prepared, synchronized to S phase, stained, and hybridized with biotinylated type II IMPDH probe using methods previously described (Senger et al., 1993; Fedorova et al., 1997).

Probe name: FFE7-Sst $\mathrm{I}$

Probe type: genomic DNA

Insert size: $4 \mathrm{~kb}$

Vector: pBluescript-SK(+)

Proof of authenticity: DNA sequencing

Gene reference: GDB:128086; Glesne and Huberman (1994)
C 1996 S. Karger AG, Basel 0301-0171/98/0824-0145\$17.50/0
Accessible online at:

http://BioMedNet.com/karger 


\section{Results}

\section{Mapping data}

Location: $3 \mathrm{p} 21$

Number of cells examined: 25

Number of cells with specific signal: 1 (1), 2 (7), 3 (9), 4 (8)

chromatids per cell

Most precise assignment: $3 \mathrm{p} 21.2$

Location of background signals: none observed

\section{References}

Collart FR, Chubb CB, Mirkin BL, Huberman E: Increased inosine-5'-phosphate dehydrogenase gene expression in solid tumor tissues and tumor cell lines. Cancer Res 52:5826-5828 (1992)

Glesne D, Collart F, Varkony T, Drabkin H, Huberman E: Chromosomal localization and structure of the human type II IMP dehydrogenase gene (IMPDH2). Genomics 16:274-277 (1993).

Glesne DA, Huberman E: Cloning and sequence of the human type II IMP dehydrogenase gene. Biochem biophys Res Comm 205:537-544 (1994).

Fedorova L, Kost-Alimova M, Gizatullin RZ, Alimov A, Zabarovska VI, Szeles A, Protopopov AI, Vorobieva NV, Kashuba VI, Klein G, Zelenin AV, Sheer D, Zabarovsky ER: Assignment and ordering of twenty-three unique NotI linking clones containing the guanosine $5^{\prime}$-monophosphate synthetase gene to human chromosome 3. Eur J Hum Genet 5:110-116 (1997).

Kiguchi K, Collart FR, Henning-Chubb C, Huberman E: Induction of cell differentiation in melanoma cells by inhibitors of IMP dehydrogenase: altered patterns of IMP dehydrogenase expression and activity. Cell Growth Diff 1:259-270 (1990).

Natsumeda Y, Carr SF: Human type I and II IMP dehydrogenases as drug targets. Ann NY Acad Sci 696:88-93 (1993)

Naylor SL et al: Report of the sixth international workshop on human chromosome 3 mapping. Cytogenet Cell Genet 72:255-270 (1996).

Senger G, Ragousis J, Trowsdale J, Sheer D: Fine mapping of the MHC class II region within $6 \mathrm{p} 21$ and evaluation of probe ordering using interphase fluorescence in situ hybridization. Cytogenet Cell Genet 64:49-53 (1993). 
Copyright: S. Karger AG, Basel 1998. Reproduced with the permission of S. Karger AG, Basel. Further reproduction or distribution (electronic or otherwise) is prohibited without permission from the copyright holder. 
Copyright: S. Karger AG, Basel 1998. Reproduced with the permission of S. Karger AG, Basel. Further reproduction or distribution (electronic or otherwise) is prohibited without permission from the copyright holder. 